\author{
ACTA MYCOLOGICA \\ Vol. 43 (1): 91-98 \\ 2008
}

\title{
New and interesting records of freshwater Verrucaria in Central Poland
}

\author{
BEATA KRZEWICKA ${ }^{1}$ and MARIUSZ HACHUŁKA ${ }^{2}$ \\ ${ }^{1}$ Laboratory of Lichenology, W. Szafer Institute of Botany, Polish Academy of Sciences \\ Lubicz 46, PL-31-512 Kraków, ibbkrzew@ib-pan.krakow.pl \\ ${ }^{2}$ Laboratory of Lichenology, Department of Mycology, University of Łódź \\ Banacha 12/16, PL-90-237 Lódź, m.hachulka@poczta.fm
}

Krzewicka B., Hachułka M.: New and interesting records of freshwater Verrucaria in Central Poland. Acta Mycol. 43 (1): 91-98, 2008.

Verrucaria madida is reported as new to Poland. Three other associated species, V.aquatilis, V.hydrela and V.rheitrophila, are compared. The known distribution in Poland and the ecology of these freshwater species are presented.

Key words: lichenized fungi, pyrenocarpous lichen, Verrucaria madida

\section{INTRODUCTION}

During studies on the lichen biota of the Wzniesienia Lódzkie Landscape Park (Central Poland) carried out by the second author, a very interesting body of material was found on submerged rocks in a watercourse. As the examination showed, individuals observed on the rocks belong to Verrucaria madida Orange species. The taxon is rare in Europe and was not reported from Poland. The species was associated with $V$. aquatilis, V.hydrela, and V.rheitrophila in the study area. Except V. aquatilis and V.rheitrophila, the species are recorded from Central Poland for the first time (Nowak 1967; Hachułka 2007).

\section{STUDY AREA}

The Wzniesienia Łódzkie Landscape Park (total area of 13767 ha) is located in Central Poland between Łódź, Stryków and Brzeziny (Fig. 1) within the fringe zone of the Wzniesienia Łódzkie Elevation mesoregion (Kondracki 2000). Springs of upland streams: Grzmiąca, Kamienna as well as Moszczenica and its tributary, Młynówka, lie in the park. The Grzmiąca and Kamienna are tributaries of the Mrożyca, whose springs are outside the park borders. The streams form the catchment area of the Bzura river and flow along incised valleys (from $2 \%$ to $4.5 \%$ ) in the spring section 


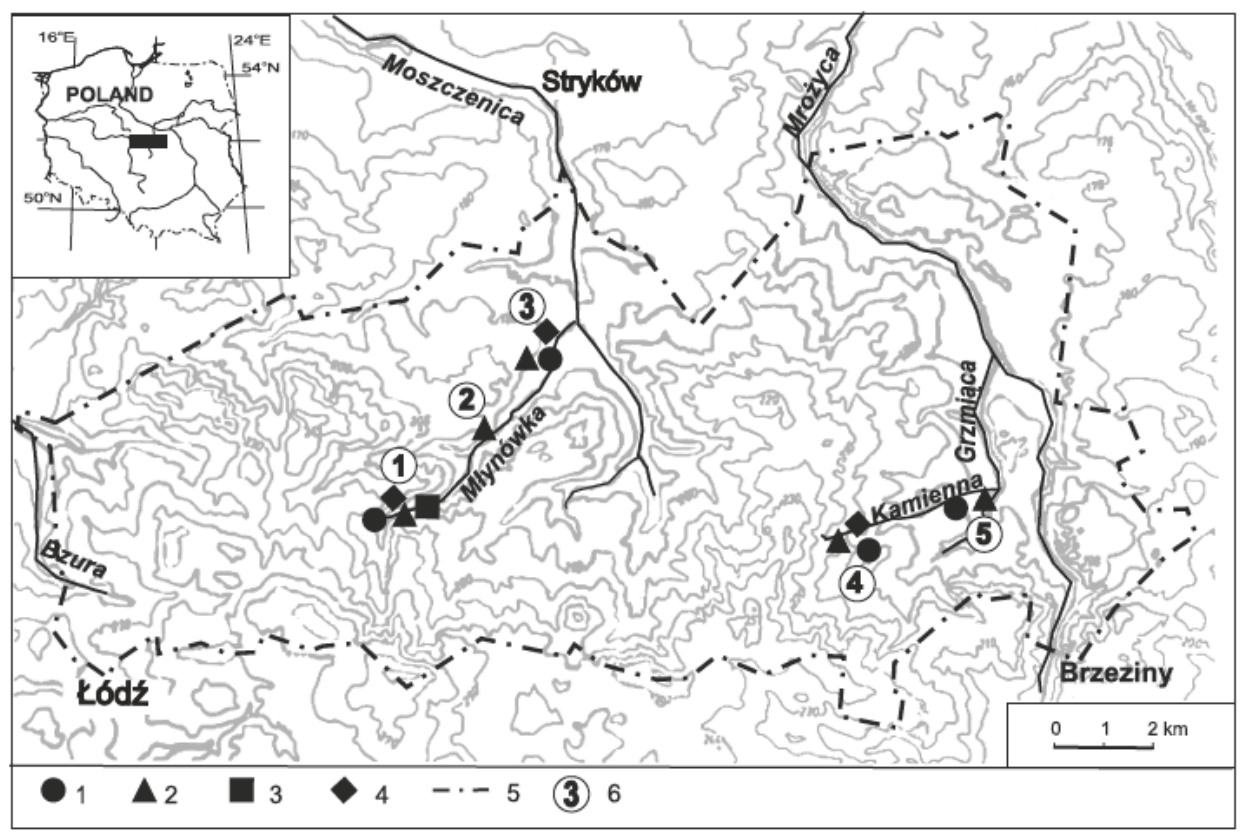

Fig. 1. Distribution of some Vernucaria species in the Wzniesienia Eódzkie Landscape Park: 1 - Verrucaria aquatilis, $2-V$. hydrela, 3 -V. madida, $4-V$.rheitrophila, 5 - border of landscape park, 6 - site.

(Kurowski 1998). The catchment area of the upper Moszczenica has the biggest relief, reaching up to $100 \mathrm{~m}$ (Moniewski 2004).

Numerous splashed or submerged stones that are a good natural substrate of freshwater lichens can be found in the Kamienna, Grzmiąca and Moszczenica streams. Stream stones are parts of gneiss, quartzite and granite (Krakowska 2004). The water quality in the fountain streams is class 1 while the $22 \mathrm{~km}$ of the Mrożyca where it flows into the park is unclassified (Raport o stanie ... 2005).

\section{MATERIAL AND METHODS}

The study is based on the material collected by M. Hachulka in the streams of the Wzniesienia Łódzkie Landscape Park. Field work was carried out by the second author during the vegetative season in 2006. Lichens were collected at 5 sites scattered in the landscape park (Fig. 1); sites 1-3 are located in the Dd 67 ATPOL grid square system, and sites 4-5 in Dd 68. Voucher specimens are available at the Herbarium Universitatis Lodziensis (LOD). Specimens were hand-sectioned (from moist thalli) and mounted in water containing a small amount of detergent. Spore measurements were taken and the structure of ascomata was examined on sections mounted in water or in ca $5 \% \mathrm{KOH}$. 


\section{RESULTS AND DISCUSSION}

\section{Verrucaria aquatilis Mudd}

Thallus thin, dark greenish brown to brownish black (blackish with the unaided eye), dull, smooth, uncracked or weakly cracks; lower part of thallus unpigmented. Perithecia forming low to moderate conical-hemispherical projections 100-240 $\mu \mathrm{m}$ diam., more or less concolorous with thallus. Exciple 120-160 $\mu \mathrm{m}$, colourless at sides and base. Involucrellum conical, often not reaching base of thallus. Asci 8-spored. Ascospores broadly ellipsoid, without perispore, 5.5-7.5 ×5.5 $\mu \mathrm{m}$ (Fig. 2).

Notes. The species is easily distinguished from other freshwater Verrucaria species by a thin, black thallus and very small, broadly ellipsoid ascospores. It could be overlooked as a dead lichen in the field. Verrucaria madida differs in having larger perithecia and ascospores and a greenish thallus.

Ecology. The species grows on the submerged acidic substrate, especially on granite rocks, in shaded places. It frequently occurs in unexposed places, mainly in the basal part of submerged pebbles. It survives well dry periods when the water level is lower. Interestingly, individuals of $V$. aquatilis were also found on roots of Alnus glutinosa submerged in the streams in the study area. It is a pioneer freshwater species which is often associated with $V$. hydrela, and later with $V$. rheitrophila and Verrucaria spp.

Distribution In PolAnd. The species is reported from many sites in clear freshwater streams of mountainous regions in southern Poland, such as the Western Carpathians (see Bielczyk 2003; Krzewicka 2006; Krzewicka, Galas 2006) and the Eastern Carpathians (Kiszka, Kościelniak 2001). Outside the Carpathians, V. aquatilis has been reported from the Wyżyna Wieluńska Upland (Nowak 1967) and from N and NE Poland (Czyżewska et al. 2002; see also Fałtynowicz, Kukwa 2006). At present, the species was also found in the lowland area of Central Poland. It is the first locality of $V$. aquatilis from this agricultural and industrial area of Poland. It is probably more frequent in Poland, and further studies should provide new records of this taxon.

Specimens examined. Poland: Wzniesienia Łódzkie Landscape Park, upper section of the Młynówka, on submerged granite rocks in shaded place, 51'50’41”N/19³4'41'E, 27 September 2006, M. Hachułka (LOD 14230, 14231); the Młynówka by the Moszczenica, with small granite dam, in the splash zone on granite rocks, 5150'44”N/19³4’33”E, 27 September 2006, M. Hachułka (LOD
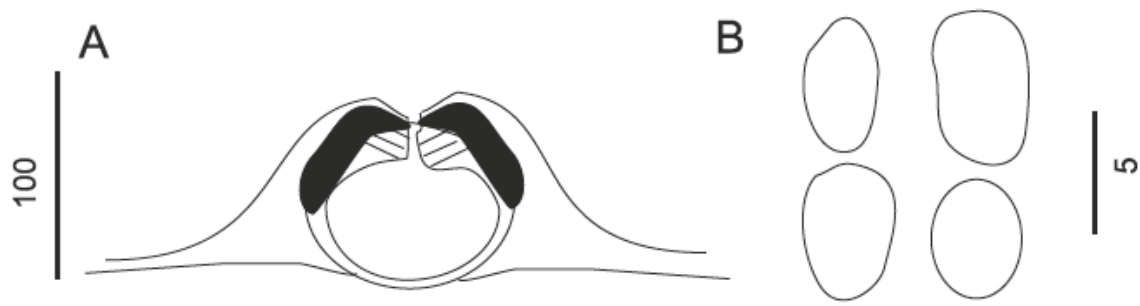

Fig. 2. Vernucaria aquatilis: A - section of perithecium, B - ascospores; scale bars: $\mathrm{A}=100$ $\mu \mathrm{m}, \mathrm{B}=5 \mu \mathrm{m}$. 
12320); upper part of the Kamienna, on submerged granite rocks in shaded place, $51^{\circ} 50^{\prime} 42^{\prime \prime} \mathrm{N} / 19^{\circ} 34^{\prime} 56^{\prime \prime} \mathrm{E}, 5$ June 2006, M. Hachulka (LOD 13713); mouth of the Kamienna, on splashed stone, in sunny place, 51 ${ }^{\circ} 50^{\prime} 37^{\prime \prime} \mathrm{N} / 9^{\circ} 34^{\prime} 58^{\prime}$ E, 23 June 2006, M. Hachułka (LOD 14348).

\section{Verrucaria hydrela Ach.}

Thallus thin, subgelatinous, continuous, smooth, grey-green to mid brown, without dark basal layer. Perithecia forming broadly conical-hemispherical mounds 100 $240 \mu \mathrm{m}$ diam., covered with thallus. Exciple 180-310 $\mu \mathrm{m}$, colourless except at apex. Involucrellum conical, often reaching base of thallus. Asci 8-spored. Ascospores ellipsoid, without perispore, 22(-26) $\times 12 \mu \mathrm{m}$ (Fig. 3).

Notes. The species is distinguished by lacking the dark basal layer of thallus, by having a subgelatinous and transparent pale green thallus when fresh and wet, and by conical involucrellum covered by a layer of thallus.

ECOLOGY. The species prefers a permanently submerged acidic substrate in exposed, sunny places. On the other hand, individuals of $V$. hydrela could be found on basic substrates (Krzewicka, Galas 2006). In this case, however, the thallus of this species grows exclusively in an acidic watercourse, on the substrate permanently submerged in water. The species can be treated as a pioneer species among freshwater taxa (Keller 2005; Krzewicka, Galas 2006). While it is the first species to colonize a new substrate in watercourses, it poorly tolerates competition from other aquatic species and is subsequently easily eliminated by other freshwater taxa. The condition of the thalli in some of the collected specimens in the study area was worse. This is also connected with the fact that some of them grow in shaded places or in places affected by longer periods without water.

Distribution IN Poland. The species is reported from Central Poland for the first time. $V$. hydrela was previously reported from scattered localities in southern and northern Poland where it was also recorded under the synonym name, V. subhydrela Servít (see Bielczyk 2003; Fałtynowicz 2003; Krzewicka 2006; Krzewicka, Galas 2006; Flakus 2007; Szymczyk 2007). At present only the general distribution of the species in Poland can be discussed as much of the verified herbarium named $V$. hydrela was misidentified. Consequently, specimens previously cited in the Polish literature should be confirmed.

SPECIMENS EXAMINED. Poland: Wzniesienia Lódzkie Landscape Park, upper section of the Młynówka, on submerged granite rocks in shaded place, 51 ${ }^{\circ} 50$ '41"N/19³4'41” $\mathrm{E}$, 27 September 2006, M. Hachułka (LOD 14230); the Młynówka by small bridge, on splashed granite rocks, in shaded place, $51^{\circ} 50^{\prime} 42^{\prime \prime} \mathrm{N} / 19^{\circ} 34^{\prime} 49^{\prime \prime} \mathrm{E}, 11$ July $2006, \mathrm{M}$.

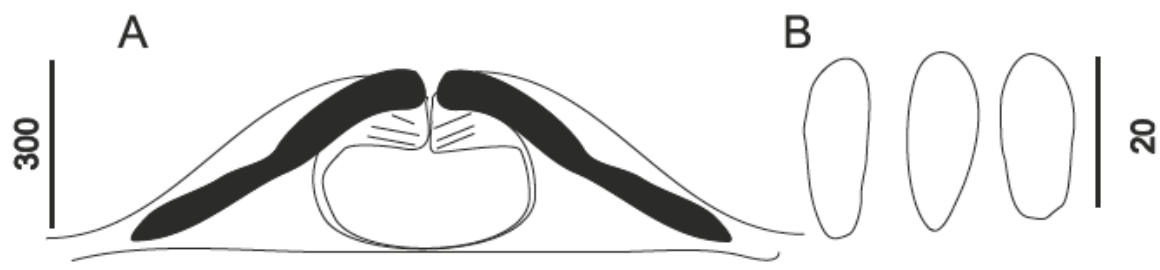

Fig. 3. Vernucaria hydrela: A - section of perithecium, B - ascospores; scale bars: $\mathrm{A}=300 \mu \mathrm{m}$, $\mathrm{B}=20 \mu \mathrm{m}$. 


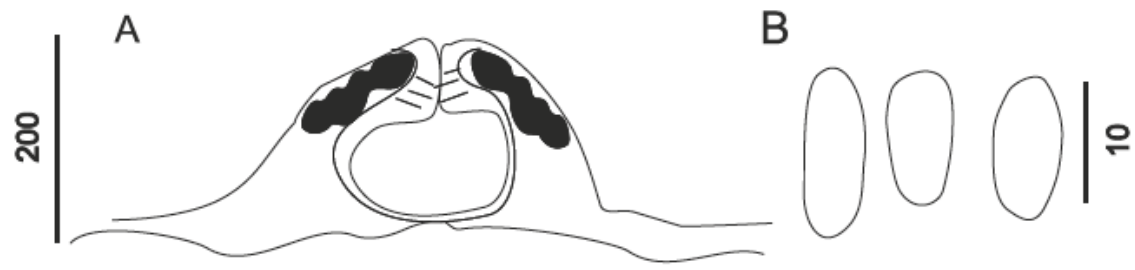

Fig. 4. Verrucaria madida: $A$ - section of perithecium, $B$ - ascospores; scale bars: $A=200 \mu \mathrm{m}$, $\mathrm{B}=10 \mu \mathrm{m}$.

Hachułka (LOD 14377); the Młynówka by the Moszczenica, near small granite dam, on splashed granite rocks, in shaded place, 51 ${ }^{\circ} 50^{\prime} 44^{\prime \prime} \mathrm{N} / 19^{\circ} 34^{\prime} 33^{\prime \prime} \mathrm{E}, 27$ September 2006, M. Hachułka (LOD 12320); the upper part of the Kamienna, on submerged granite rocks in shaded place, $51^{\circ} 50^{\prime} 42^{\prime \prime N} / 9^{\circ} 34 ' 56^{\prime \prime} \mathrm{E}, 5$ June 2006, M. Hachułka (LOD 13713); the mouth of the Kamienna, on splashed granite rocks, in sunny place, 5150'37'N/19³4'58'E, 23 June 2006, M. Hachułka (LOD 14236).

Verrucaria madida Orange

Thallus dark green to greenish black, thin, smooth, uncracked. Perithecia forming low to moderate conical-hemispherical projections 200(-420) $\mu \mathrm{m}$ diam. Exciple 140-290 $\mu \mathrm{m}$ diam. colourless or brown below. Involucrellum conical, or somewhat spreading at sides and then slightly curved down. Asci (3-)4(-5)-spored. Ascospores broadly ellipsoid, without perispore, $12(-16) \times 7 \mu \mathrm{m}$ (Fig. 4).

NOTES. The species can be easily distinguished by 4 -spored asci which are unique in the genus. Verrucaria aquatilis differs in having smaller perithecia and ascospores, V. rheitrophila differs in having immersed perithecia and the presence of punctae in the thallus, and $V$. hydrela differs in having larger perithecia and ascospores. The present individuals have spores slightly longer than those described in the protologue (Orange 2004), reaching up to $16 \mu \mathrm{m}$, and a darker thallus; they contain, however, typical 4-spored asci.

ECOLOGY. The species occurs on frequently immersed siliceous rocks in streams, in slightly shaded places, in woodland, grows together with V. aquatilis and V. rheitrophila.

Distribution. New to Poland. The species was reported from a few scattered localities in NW Europe, in Wales, France and Norway (Orange 2004). According to Orange, it is probably more frequent but is overlooked.

SPECIMENS EXAMINED. Poland: Wzniesienia Lódzkie Landscape Park, upper section of the Młynówka, on submerged granite rocks in shaded place, $51^{\circ} 50^{\prime} 41^{\prime \prime} \mathrm{N} / 19^{\circ} 34^{\prime} 41^{\prime \prime} \mathrm{E}$, 27 September 2006, M. Hachułka (LOD 14234).

ADDITIONAL SPECIMENS EXAMINED. Great Britain: Wales, V.C.42, Breconshire: Brecon Beacons, west of the Beacons Reservoir, by Nant Pennig, 22/977190, alt. $510 \mathrm{~m}$, in calcareous streamlet on rocky bank on Old Red Sandstone, 1994, Orange 9986 (NMW.C.1999.011.159) - material quoted in the protologue.

Verrucaria rheitrophila Zschacke

Thallus greyish or brownish green to dark green, well-developed, $60-95 \mu \mathrm{m}$ thick, usually uncracked, but sometimes with sparse or numerous cracks. Thallus surface smooth or with sparse to numerous black punctae. Exciple 110-210 $\mu \mathrm{m}$, colourless 

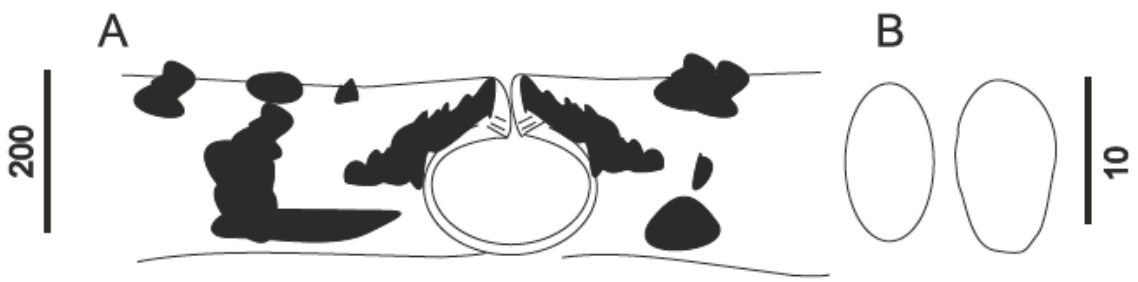

Fig. 5. Vernucaria rheitrophila: $\mathrm{A}$ - section of perithecium, $\mathrm{B}$ - ascospores; scale bars: $\mathrm{A}=200$ $\mu \mathrm{m}, \mathrm{B}=10 \mu \mathrm{m}$.

or partly brown Involucrellum well-developed in the upper half of the exciple, often spreading outwards and downwards and grading into the punctae of the upper layer of the medulla. Asci 8-spored. Ascospores ellipsoid, without perispore, $12(-16) \times 7.5$ $\mu \mathrm{m}$ (Fig. 5).

Notes. The species is easily distinguished by immersed perithecia, visible as black dots, and by black punctae giving the thallus a scabrid appearance. Punctae are most easily seen in thin thalli, but are immersed in thicker thalli.

ECOLOGY. The species occurs on siliceous rocks, in exposed places, such as on the vertical surface of rocks. Growth conditions seem to be excellent in the study area. Different thalli, from juvenile forms to well-developed adult ones, were found in the streams examined; it seems to be common in these watercourses.

Distribution In Poland. The species is known from scattered sites in the Polish Carpathians, where it is abundant in clear streams at lower altitudes (Bielczyk 2003; Kościelniak, Kiszka 2003). It was recorded at one site in the Kańczowa stream in the Bieszczady Mts (Kiszka, Kościelniak 2001) and in many sites in the Beskidy Mts (Nowak 1965, 1998; Kiszka 1967, 1985, 1998; Kozik 1977). Outside the Carpathians, V. rheitrophila is known from the Wyżyna Wieluńska Upland (Nowak 1967), where it grows on siliceous rocks. At present abundant populations of the species are confirmed from lowland areas of Central Poland, where it was previously reported by Hachułka (2007).

Specimens eXamined. Poland: Wzniesienia Łódzkie Landscape Park, upper section of the Młynówka, on submerged granite rocks in shaded place, $51^{\circ} 50^{\prime} 41^{\prime \prime} \mathrm{N} / 19^{\circ} 34^{\prime} 41^{\prime \prime} \mathrm{E}, 27$ September 2006, M. Hachulka (LOD 14231), the Młynówka by the Moszczenica, near small granite dam, on submerged granite rocks in shaded place, 51 ${ }^{\circ} 50^{\prime} 44^{\prime \prime} \mathrm{N} / 9^{\circ} 34^{\prime} 33^{\prime \prime} \mathrm{E}, 27$ September 2006, M. Hachułka (LOD 14375); the upper part of the Kamienna, on submerged granite rocks in shaded place, $51^{\circ} 50^{\prime} 42^{\prime \prime} \mathrm{N} / 19^{\circ} 34^{\prime} 56^{\prime \prime} \mathrm{E}, 5$ June 2006, M. Hachułka (LOD 13713); the mouth of the Kamienna, in splash zone on granite rocks in shaded place, $51^{\circ} 50^{\prime} 37^{\prime \prime} \mathrm{N} / 1^{\circ} 34^{\prime} 58^{\prime \prime} \mathrm{E}$, 5 June 2006, M. Hachułka (LOD 14237, 12243).

Acknowledgements. The authors thank Professor K. Czyżewska (Eódź) for her assistance and support during the preparation of the manuscript. The study was supported by the Ministry of Science and Higher Education, grant no. N305 04332 . 


\section{REFERENCES}

Bielczyk U. 2003. The lichens and allied fungi of the Polish Western Carpathians. (In:) U. Bielczyk (ed.). The lichens and allied fungi of the Polish Carpathians - an annotated checklist. W. Szafer Institute of Botany, Polish Academy of Sciences, Kraków: 23-232.

Czyżewska K., Cieśliński S., Motiejūnaité J., Kolanko K. 2002. The Budzisk nature reserve as a biocentre of lichen diversity in the Knyszyńska Large Forest (NE Poland). Acta Mycol. 37 (1/2): 77-92.

Fałtynowicz W. 2003. The lichens, lichenicolous and allied fungi of Poland - an annotated checklist. (In:) Z. Mirek (ed.). Biodiversity of Poland 6. W. Szafer Institute of Botany, Polish Academy of Sciences, Kraków: 435 pp.

Fałtynowicz W., Kukwa M. 2006. List of lichens and lichenicolous fungi of Gdańskie Pomerania. Acta Botanica Cassubica, Monogr. 1-98.

Flakus A. 2007. Lichenized and lichenicolous fungi from mylonitized areas of the subnival belt in the Tatra Mountains (Western Carpathians). Ann. Bot. Fennici 44: 427-449.

Hachułka M. 2007. Porosty naskalne w środowisku przyrodniczym Parku Krajobrazowego Wzniesień Łódzkich. (In:) E. Kępczyńska, J. Kępczyński (eds). Botanika w Polsce - sukcesy, problemy, perspektywy. Streszczenia referatów i plakatów 54 Zjazdu Polskiego Towarzystwa Botanicznego. Szczecin: 168.

Keller C. 2005. Artificial substrata colonized by freshwater lichens. Lichenologist 37 (4): 357-362.

Kiszka J. 1967. Porosty Beskidu Śląskiego. Roczn. Nauk.-Dydakt. WSP w Krakowie 28: 1-91.

Kiszka J. 1985. Porosty Pogórza Spiskiego. Studia Ośrodka Dokumentacji Fizjograficznej PAN 13: 213-243.

Kiszka J. 1998. Lichen flora as indicative of the enviromental degradation in the Czarna Wisełka and Biała Wisełka catchments. Studia Naturae 44: 113-123.

Kiszka J., Kościelniak R. 2001. Nowe i rzadkie gatunki porostów (Lichenes) w Bieszczadzkim Parku Narodowym i jego otulinie. Część III. Roczniki Bieszczadzkie 9 (2000): 27-32.

Kondracki J. 2000. Geografia regionalna Polski. PWN, Warszawa, 440 pp.

Kościelniak R, Kiszka J. 2003. The lichens and allied fungi of the Polish Eastern Carpathians. (In:) U. Bielczyk (ed.). The lichens and allied fungi of the Polish Carpathians - an annotated checklist. W. Szafer Institute of Botany, Polish Academy of Sciences, Kraków: 233-294.

Kozik R. 1977. Porosty (Lichenes) Pogórza Rożnowsko-Ciężkowskiego. Fragm. Flor. Geobot. 23 (2): 215-252.

Krakowska K. 2004. Głazy narzutowe w Parku Krajobrazowym Wzniesień Łódzkich. Przewodnik. Dyrekcja Parku Krajobrazowego Wzniesień Łódzkich, Łódź.

Krzewicka B. 2006. Wodne gatunki porostów z rodzaju Verrucaria w potoku Chochołowskim w Tatrach. Materiały III Ogólnopolskiej Konferencji Przyroda Tatrzańskiego Parku Narodowego a człowiek 2005. (In:) Z. Mirek, B. Godzik (eds). Tatrzański Park Narodowy na tle innych górskich terenów chronionych. Nauki Biologiczne, Zakopane: 51-56.

Krzewicka B., Galas J. 2006. Ecological notes on Verrucaria aquatilis and V. hydrela in the Polish Tatra Mountains. (In:) A. Lackovičová, A. Guttová, E. Lisická, P. Lizoň (eds). Central European lichens diversity and threat. Mycotaxon: 193-204.

Kurowski J.K. (ed.). 1998. Park Krajobrazowy Wzniesień Łódzkich. Monografia. Wyd. Eko-Wynik, Łódź, $182 \mathrm{pp}$.

Moniewski P. 2004. Źródła okolic Łodzi. Acta Geogr. Lodz. 87: 1-140.

Nowak J. 1965. Porosty Beskidu Małego. Fragm. Flor. Geobot. 11 (3): 209-242.

Nowak J. 1967. Porosty Wyżyny Wieluńskiej. Acta Mycol. 3: 209-242.

Nowak J. 1998. Porosty Beskidów Wyspowego i Żywieckiego, Pasma Jałowca i Masywu Babiej Góry. Monogr. Bot. 83: 1-131.

Orange A. 2004. A remarkable new freshwater Verrucaria from Europe. Lichenologist 36 (6): 349-354.

Raport o stanie środowiska w województwie łódzkim w 2004 roku. 2005. Wojewódzki Inspektorat Ochrony Środowiska w Łodzi. Oficyna wydawnicza, Łódź: 116-143.

Szymczyk R. 2007. Rzadkie i interesujące gatunki porostów i grzybów naporostowych na Wysoczyźnie Elbląskiej (północna Polska). Fragm. Flor. Geobot. Pol. 14 (1): 167-173. 
Nowe dane o wodnych gatunkach Verrucaria z Polski Środkowej

\section{Streszczenie}

W pracy przedstawiono cztery gatunki porostów z rodzaju Verrucaria: V. aquatilis, V. hydrela, $V$. madida i $V$. rheitrophila, zebrane w strumieniach zlokalizowanych w Parku Krajobrazowym Wzniesień Łódzkich. Materiał zebrany w roku 2006 przez M. Hachułkę został zrewidowany lub oznaczony przez pierwszego autora.

Verrucaria madida jest gatunkiem nowym dla bioty Polski. Porost ten ma plechę ciemno-zieloną do zielonawoczarnej, inwolukrelum stożkowate lub po bokach rozpościerające się i wówczas lekko powyginane (faliste), worki z (3-)4(-5) zarodnikami; zarodniki jednokomórkowe elipsoidalne 12(-17) x $7 \mu \mathrm{m}$. Według Orange (2004) V. madida znany jest z kilku rozproszonych stanowisk w Europie Północno-Zachodniej, z Wielkiej Brytanii (Walia), Francji oraz z Norwegii. W parku krajobrazowym gatunek ten, wraz z towarzyszącymi mu V. aquatilis, $V$. hydrela i $V$. rheitrophila odnotowano w odcinku źródłowym w Młynówce na pierwszym stanowisku, na kwaśnych kamieniach zanurzonych w wodzie. $V$. hydrela występuje na wszystkich badanych stanowiskach i jest podawana po raz pierwszy z Polski Środkowej. V. rheitrophila odnotowano w Młynówce na pierwszym i trzecim stanowisku oraz w Kamiennej. Ostatni gatunek był podawany z Polski Środkowej jedynie przez Nowaka (1967) z Wyżyny Wieluńskiej (łącznie z V. aquatilis) i Hachułkę (2007) ze Wzniesień Łódzkich. 